\title{
Selebriti dan Komodifikasi Kapital di Media Sosial
}

\author{
Sutriono, S. Sos ${ }^{1}$, Dr. Haryatmoko \\ ${ }^{1}$ Mahasiswa Pascasarjana Ilmu Komunikasi Departemen Ilmu Komunikasi Fakultas Ilmu Sosial dan Ilmu \\ Politik Universitas Indonesia Kampus Depok, sutriono@ui.ac.id \\ ${ }^{2}$ Staf Pengajar Pascasarjana Ilmu Komunikasi Departemen Ilmu Komunikasi Fakultas Ilmu Sosial dan Ilmu \\ Politik Universitas Indonesia Kampus Depok, jhmoko59@gmail.com
}

\begin{abstract}
Abstrak: Media sosial sebagai bentuk platform web 2.0 mengalihkan penekanan konsumsi layanan internet menjadi berbasis interaktif dan kolaboratif, menciptakan bentuk interaksi antar individu, kelompok masyarakat, organisasi dan publik. Tidak hanya tokoh dan politisi dunia, selebriti juga ambil bagian dalam interaktifitas dalam media sosial. Media sosial telah menjadi arena sosial global yang menjadi tempat reproduksi budaya yang dilakukan terus menerus yang melibatkan individu dalam kelas-kelas sosial. Sebagai wahana kontestasi dibutuhkan keahlian, dan modal tertentu yang disebut oleh Bourdieu dengan istilah kapital. Makalah dengan metode studi pustaka ini bertujuan untuk mengetahui bagaimana mobilisasi kapital yang dimiliki selebriti dalam media sosial sebagai ruang sosial yang dikenal dengan arena. Pentingnya kapital dalam sebuah arena menunjukkan bahwa media sosial bukanlah sekedar bentuk platform yang partisapatif, melainkan sebuah arena kontestasi sosial bagi individu didalamnya. Selebriti hadir ditengah publik lewat sosial media dengan kekuatan kapitalnya khususnya kapital simbolis yang didapatkan akibat akumulasi visibilitas media yang dihasilkan dari representasi media berulang kerap dikonversi menjadi kapital yang lain dalam banyak hal seperti marketing dan periklanan. Media sosial sebagai arena yang muncul dalam bentuk digital sebenarnya tidak berbeda dengan arena dalam bentuk fisik. Dalam arena terdapat usaha melakukan dominasi kelas sosial tertentu dengan memanfaatkan kapital yang dimiliki, termasuk oleh selebriti melalui distinction untuk memperlihatkan perbedaan kelas. Selain selebriti yang mendapatkan visibilitas dari media, di media sosial juga muncul fenomena micro celebrity. Komodifikasi selebriti menjadi produk pemasaran telah meningkatkan kemampuan kapital lainnya, khususnya kapital ekonomi melalui kehadiran follower. Dominasi kelas sosial selebriti terkadang tidak disadari oleh follower, dan hanya menguntungkan pada selebriti. Ketidaksadaran follower yang dibuktikan dengan tindakan mengkonsumsi produk milik selebriti agar merasa sejajar. Penciptaan selera yang sama hanyalah bentuk distinction lain yang dilakukan untuk melanggengkan kelas dominan selebriti melalui akumulasi kapital ekonomi.
\end{abstract}

Kata Kunci: Selebriti; Media Sosial; Kapital; Arena; Komodifikasi; Bourdieu; 


\title{
Selebriti dan Komodifikasi Kapital di Media Sosial
}

\author{
Sutriono, S. Sos ${ }^{1}$, Dr. Haryatmoko \\ ${ }^{1}$ Mahasiswa Pascasarjana Ilmu Komunikasi Departemen Ilmu Komunikasi Fakultas Ilmu Sosial dan Ilmu \\ Politik Universitas Indonesia Kampus Depok, sutriono@ui.ac.id \\ ${ }^{2}$ Staf Pengajar Pascasarjana Ilmu Komunikasi Departemen Ilmu Komunikasi Fakultas Ilmu Sosial dan Ilmu \\ Politik Universitas Indonesia Kampus Depok, jhmoko59@gmail.com
}

\section{Pendahuluan}

Dampak perkembangan internet dan teknologi informasi komunikasi (TIK) telah membawa banyak perubahan dalam kehidupan sosial masyarakat. Beberapa hal yang dapat dilihat dari imbas tranformasi TIK adalah fenomena munculnya platform teknologi yang memudahkan manusia berinteraksi satu sama lain melalui media digital, salah satunya dengan media sosial. Kehadiran media sosial sebagai media komunikasi di era digital sebagai transformasi web 1.0 yang bersifat statis dimana orang hanya bisa melihat informasi melalui halaman web yang dikenal dengan era "Read-Only Web" dan dibuat oleh penyedia layanan lebih untuk menerbitkan katalog online untuk iklan produk atau layanan. Media sosial sebagai bentuk platform web 2.0 mengalihkan penekanan konsumsi layanan internet menjadi berbasis interaktif dan kolaboratif, menciptakan bentuk interaksi antar individu, kelompok masyarakat, organisasi dan publik (Solanki \& Dongaonkar, 2016). Tercatat pada April 2018, penetrasi internet di seluruh dunia telah menjangkau lebih dari 54\% wilayah dunia dengan menempatkan Facebook sebagai platform jejaring media sosial yang paling banyak digunakan dengan jumlah pengguna 2,23 milyar dan menempati peringkat pertama media sosial yang paling banyak digunakan di Indonesia sebanyak 140 juta pengguna (wearesocial.com, 2018c).

Perkembangan yang luar biasa pesat pengguna media sosial juga telah dimanfaatkan oleh banyak individu seperti tokoh-tokoh dunia, Burson-Marsteller, sebuah perusahaan global yang bergerak di bidang konsultan komunikasi melakukan survey pada tahun 2017 dengan mengidentifikasi 856 akun Twitter yang dikelola oleh kepala negara dan pemerintahan, serta menteri luar negeri di 178 negara, dan menempatkan Paus dan Presiden Amerika Serikat Donald Trump sebagai pemimpin dengan follower lebih dari 30 juta. Hasil survei memperlihatkan bagaimana media sosial telah menjadi hal penting bagi diplomasi yang mendorong penggunanya menjadikan media sosial tidak sekedar partisipasi tapi juga informasi (Burson-Marstellery, 2017). 
Tidak hanya tokoh dan politisi dunia, selebriti juga ambil bagian dalam interaktifitas dalam media sosial. Bahkan popularitas selebriti lebih dominan di dalam media sosial yang dibuktikan oleh banyaknya jumlah pengikut (follower) dibandingkan profesi lainnya. Deretan selebriti dunia yang pengikutnya lebih dari 100 juta seperti Selena Gomez, Christiano Ronaldo, Ariana Grande, Beyonce dan Taylor Swift (topteny.com, 2018). Di Indonesia, dengan penetrasi internet yang menjangkau 50\% wilayahnya telah menempatkan media sosial sebagai platform media digital yang paling banyak digunakan dengan rata-rata penggunaan lebih dari 3,5 jam tiap harinya, berada di urutan ke tiga setelah Filipina dan Brasil (wearesocial.com, 2018a). Beberapa nama selebriti Indonesia dengan pengikut paling banyak antara lain seperti Ayu Tingting, Rafi Ahmad, Laudya Cynthia Bella dan Syahrini yang mempunyai pengikut lebih dari 19 juta pengguna Instagram (tribunnews.com, 2017).

Media sosial telah menjadi wahana interaksi sosial global yang menjadi tempat reproduksi budaya yang dilakukan terus menerus yang melibatkan individu dalam kelas-kelas sosial. Sebagai wahana kontestasi dibutuhkan keahlian, dan modal tertentu yang disebut oleh Bourdieu dengan istilah kapital. Kapital dalam kelas sosial terdiri dari tiga dimensi yakni ekonomi, budaya, dan sosial yang dapat digunakan dalam kehidupan sosial dan dapat dilegitimasi menjadi kapital simbolik. (P Bourdieu, 2013).

\section{Rumusan Masalah}

Kehadiran media sosial dalam kehidupan manusia telah banyak digunakan oleh individu secara pribadi maupun institusi, termasuk selebriti. Sebagai wahana interaksi dan reproduksi budaya dibutuhkan kapital-kapital tertentu didalamnya. Makalah ini bertujuan untuk memaparkan bagaimana mobilisasi kapital yang dimiliki selebriti dalam media sosial dengan menggunakan pendekatan teori yang dikemukakan oleh Pierre Bourdieu.

\section{Tinjauan Pustaka}

\section{1 Media Sosial}

Media sosial sebagai bentuk web 2.0 mencakup berbagai platform seperti jejaring sosial telah membawa perubahan yang cepat pada komunikasi dan hubungan masyarakat. Teknologi ini telah mengalihkan penekanan layanan internet dari konsumsi berbasis satu arah menjadi interaktif dan kolaboratif, menciptakan peluang baru untuk interaksi antara organisasi dan publik. Media sosial digunakan oleh perusahaan bisnis dan organisasi pemerintah sebagai alat komunikasi. Organisasi secara aktif memanfaatkan media sosial 
untuk periklanan dan pemasaran, berkomunikasi dengan pelanggan, membangun hubungan dengan pelanggan, merek dan lain-lain (Kim, Seely, \& Jung, 2017). Penggunaan media sosial yang efektif merupakan indikasi penting keberhasilan teknologi, yang pada gilirannya berdampak pada organisasi dan mempunyai manfaat aktual yang diterima organisasi dari penggunaan media sosial (Parveen, 2012).

Media sosial juga dikenal dengan Social Networking Sites, adalah layanan berbasis internet yang memungkinkan individu untuk membuat, membagi, dan mencari konten, sekaligus berkomunikasi dan bekerja sama dengan orang lain (Kim et al., 2017). Kita dapat mengakses media sosial melalui perangkat mobile (gadget) seperti laptop, komputer, tablet, maupun smartphone yang memiliki koneksi internet. Media sosial sendiri dapat diakses dalam bentuk sebuah website maupun aplikasi berupa software. Mobile media sosial memungkinkan individu untuk menggunakan media sosial melalui smartphone (Humphreys, 2007). Di era modern sekarang ini, terdapat beragam media sosial yang dapat kita gunakan untuk berkomunikasi. Beberapa media sosial yang sedang populer dan banyak digunakan antara lain Twitter, YouTube, Instagram dan Facebook. Perkembangan media sosial online muncul dalam berbagai medium yang memberikan peluang bagi individu atau organisasi untuk tujuan public relations maupun jurnalistik. Istilah media sosial juga didefinisikan secara berbeda oleh beberapa peneliti sebagai "aplikasi berbasis internet" (Blackshaw 2006), "berbagai sumber baru" (Mangold, Faulds 2009), "saluran media online (Mayfield, 2008) (Coman \& Paun, 2010).

Kehadiran dan popularitas media sosial telah menciptakan peluang bagi pemasar dengan cara beriklan di media sosial. Melalui media sosial, penargetan spesifik individu atas dasar karakteristik yang ditentukan oleh pemasar dengan menentukan variabel geografis, demografi, dan psikografis yang telah disajikan oleh media sosial telah memudahkan pemasar menentukan bentuk dan target iklan. Selain itu, dengan media sosial pemasar dapat membuat business page yang dibentuk sedemikian rupa untuk menciptakan kedekatan dengan pengguna media sosial dalam bentuk format konten yang menarik dan tidak membosankan (Gironda \& Korgaonkar, 2014). Facebook sebagai salah satu media jejaring sosial juga menyajikan data demografis yang dapat digunakan oleh pemasar untuk memasang iklan yang tepat berdasarkan beberapa karakteristik domografis seperti berdasarkan area tertentu (facebook.com, 2018). 


\section{2 Selebriti}

Selebriti (celebrity) berasal dari bahasa latin celebrem yang mempunyai arti ketenaran atau sedang menjadi “tontonan atau sedang kerumunan”. Célèbre dalam bahasa perancis juga mengartikan selebriti sebagai hal "terkenal di masyarakat" (Rojek, 2001). Fenomena selebriti di kenal tidak hanya ada pada masa modern. Sejarah selebriti bisa ditelusuri dari masa ke masa ketika peran agama sangat mendominasi. Pada era agama menjadi kekuatan utama dalam sosial masyarakat, selebriti diidentikkan dengan tokoh-tokoh yang terdapat dalam kitab suci. Seiring dengan perubahan waktu, raja menggantikan tokoh-tokoh Alkitab sebagai hamba Tuhan di Bumi yang menjadi dasar status selebriti mereka. Kemudian pemahaman selebriti bergeser ketika kemunculan suasana demokratis, pemimpin diktator dan pemimpin politik kehilangan pamornya digantikan figur tokoh masyarakat baru. Budaya kapitalis dan munculnya masyarakat konsumerisme pada awal abad 20 menjadi titik kunci bagaimana produk membutuhkan konsumen, peran baru diciptakan untuk menjadi 'duta produk' guna mendukung dan mempromosikan produk barang-barang. Dan seiring dengan bangkitnya konsumerisme, pertumbuhan media massa mengubah apa yang dimaksud dengan selebriti dengan menampilkan sejumlah orang terkenal ke mata publik untuk tujuan tertentu (Laughey, 2010).

Rojek mendeskripsikan selebriti dalam era modernitas yang identik dengan konsumerisme, hal ini memunculkan kondisi interaksi sosial yang terus menerus dalam budaya masyarakat yang meningkatkan perubahan dalam kehidupan sosial dan ekonomi. Beberapa karekteristik selebriti di era modern antara lain;

1. Glamor dan kemasyhuran selebriti. Glamor diartikan dengan pengakuan publik yang menguntungkan, sedangkan kemasyhuran adalah sebaliknya yaitu bentuk pengakuan yang tidak menguntungkan. Kedua kata tersebut merupakan arti lain dari ketenaran, sebagai salah satu hal yang dibutuhkan oleh selebriti. Secara sadar atau tidak, baik hal positif maupun negatif yang dimiliki oleh individu membuat dirinya menjadi tenar dapat menjadikan dia sebagai selebriti.

2. Pengakuan selebriti. Kehadiran selebriti sebagai fabrikasi budaya dan dengan bantuan media telah membantu selebriti memperoleh pengakuan publik. Dengan bantuan perantara kebudayaan yang ada dalam industri media dan konsumerisme seperti humas, tenaga pemasaran, promotor, fotografer, pelatih kebugaran, staf tata pakaian, ahli kosmetik, dan asisten pribadi maka selebriti dihadirkan untuk membuat presentasi publik tentang kepribadian yang menghasilkan daya tarik abadi bagi para penonton maupun penggemar. 
3. Pemisahan diri sebagai pribadi dan konsumsi publik. Status selebriti kerap meghadirkan permasalahan pemisahan dirinya sebagai individu pribadi dan sebagai milik publik karena tidak jelasnya batas antara keduanya.

4. Pembeda yang membuat ketenaran dan terkenal. Untuk menjadi selebriti, individu harus mempunyai pembeda yang khusus dan memunculkan ketenaran dimana mana dalam kehidupan sosial yang menonjol seperti kecerdasan, kecantikan, keberanian, kecakapan, prestasi atau anugerah mereka (Rojek, 2001).

Sejalan dengan pendapat Rojek, menurut Silvera dan Austad (2004) selebriti merupakan orang-orang yang menikmati pengakuan publik oleh sebagian besar kelompok orang tertentu dan mereka memiliki keunikan yang berbeda yang terkadang menggunakan pengakuan itu atas nama konsumen baik dengan tampil bersama dalam iklan (McCracken, 1989) (Malik \& Sudhakar, 2014). Untuk mempertahankan status selebritinya, selebriti berusaha untuk tampil dengan gaya unik dan mempertahankan gaya interaksi para-sosial yang mengacu pada keakraban antara kepribadian melalui media dan khalayak melalui pertunjukan, misalnya gaya percakapan intim (close-up) yang membantu memupuk keterikatan pribadi selebriti pada pendengar dan pemirsa (Laughey, 2010:117).

\section{3 Kapital}

Dalam tulisan yang ditulis oleh Bourdieu The Forms of Capital, dunia sosial merupakan bentuk dari akumulasi historis yang didalamnya individu sebagai agen membutuhkan kapital-kapital untuk memainkan peran dalam kehidupan sosialnya. Kapital yang dimiliki oleh individu memutuhkan waktu untuk berakumulasi dan mempunyai kapasitas potensial untuk menghasilkan keuntungan dan untuk mereproduksi kapital dalam bentuk sama maupun diperluas bentuknya menjadi jenis kapital yang berbeda dan mempunyai kecenderungan untuk dipertahankan keberadaannya. Peluang keberhasilan individu sebagai aktor dalam praktik sosial ditentukan oleh bagaimana individu mendistribusikan kapital yang dimiliki (Bourdieu, 1985).

Mobilisasi kapital bergantung pada bidang di mana ia berfungsi, dan dengan memperhitungkan kompensasi biaya transformasi yang merupakan prasyarat untuk keampuhannya di bidang yang bersangkutan, Kapital dapat menampilkan bentuknya dalam tiga bentuk dasar yakni sebagai kapital ekonomi, yang segera dan langsung dikonversi menjadi kekuatan finasial (uang) dan dapat dilembagakan dalam bentuk hak milik, sebagai 
kapital budaya yang dapat dikonversi, pada kondisi tertentu seperti menjadi kapital ekonomi dan dapat dilembagakan dalam bentuk kualifikasi pendidikan, dan sebagai kapital sosial, yang terdiri dari kewajiban sosial (koneksi), yang dapat dikonversi, dalam kondisi tertentu, menjadi kapital ekonomi dan dilembagakan dalam bentuk gelar bangsawan (Bourdieu, 1985:2). Sedangkan kapital simbolik merupakan kapital yang membutuhkan pengakuan atau legitimasi dari dari kelompok sosial (Haryatmoko, 2015) yang seringkali membutuhkan simbol-simbol kekuasaan seperti pangkat, simbol kemewahan, dan ketenaran,

\section{Diskusi dan Analisis}

Makalah ini ditulis dilakukan dengan menggunakan metode studi kepustakaan atau literatur, yang dilakukan secara sistematis untuk mengumpulkan, mengolah, dan menyimpulkan data dengan menggunakan metode/teknik tertentu guna mencari jawaban atas permasalahan yang dihadapi dalam penelitian kepustakaan dengan menganalisa buku, jurnal, berita-berita terkait topik penulisan. Dari perumusan masalah dan kajian literatur yang dilakukan ditemukan beberapa tema keterkaitan antara selebriti, dan media sosial dengan menggunakan pemikiran Pierre Bourdieu.

\section{Media Sosial sebagai Arena}

Transformasi web menjadi platform media sosial sangat erat kaitannya dengan perkembangan perangkat teknologi dan penyebaran internet yang telah menghubungkan orang-orang secara global. Tercatat pada April 2018, penetrasi internet di seluruh dunia telah menjangkau lebih dari 54\% wilayah dunia dengan menempatkan Facebook sebagai platform jejaring media sosial yang paling banyak digunakan dengan jumlah pengguna 2,23 milyar dan menempati media sosial sebagai platform yang paling banyak digunakan. Dan di Indonesia tercatat sebanyak 140 juta pengguna telah menggunakan media sosial, sebagai platform yang paling banyak digunakan (wearesocial.com, 2018b). Perubahan teknologi dari yang cenderung pasif ke aktif juga berdampak pada munculnya saluran baru yang lebih personal seperti blog dan media sosial (Phillips \& Young, 2009).

Tabel IV.1 Perbandingan Karakteristik Web 1.0 dan 2.0

\begin{tabular}{|l|l|l|}
\hline \multirow{3}{*}{ Gaya Narasi } & Jurnalisme Tradisional & Blog/ Media Sosial \\
& Tidak Memihak & Personal \\
\cline { 2 - 3 } & Netral & Opini \\
\cline { 2 - 3 } & Sumber dua sisi (both sides) & one side \\
\hline Pendekatan ke & Khalayak pasif & Khalayak aktif \\
\hline
\end{tabular}




\begin{tabular}{|l|l|l|}
\hline Khalayak dan Asal \begin{tabular}{l} 
Cerita \\
\cline { 2 - 2 }
\end{tabular} & Terstruktur & Fragmen \\
\cline { 2 - 3 } & Menjawab pertanyan dasar $5 \mathrm{~W}+1 \mathrm{H}$ & Tidak lengkap \\
\cline { 2 - 3 } & Sumber dan kredibilitas jelas & Kredibilitas berupa hyperlinks \\
\cline { 2 - 3 } & \multicolumn{2}{|}{} \\
\hline
\end{tabular}

Awalnya, kemunculan web 1.0 yang digagas oleh Tim Berners-Lee pada tahun 1989 lebih bertujuan untuk mempublikasikan informasi kepada siapa saja setiap waktu dan membangun keberadaan online menerbitkan katalog di web untuk iklan produk atau informasi layanan (Solanki \& Dongaonkar, 2016). Web 2.0 kemudian memperbaharui karakteristik web terdahulu yang bersifat statis menjadi partisipatif pada bentuk ini. Bentuk web pada era ini tumbuh pesat dalam berbagai platform seperti blog, chatting, layanan hosting, aplikasi web, voice over IP, email, pesan instan, berbagi gambar, weblog, dan lain sebagainya yang memungkinkan terjadinya jenis interaktivitas online. Karakteristik web 2.0 telah menjadi platform yang diminati dapat dikatakan telah menciptakan jaringan dengan kemampuan publikasi oleh pengguna lain, mempunyai arsitektur yang mendukung aksi partisipatif, kolaboratif dan memiliki sistem terdesentralisasi yang memberikan ruang bagi sebagian besar pengguna yang menggunakan layanan tertentu (Sigh, Bebi, \& Gulati, 2011).

Dari sisi kritis, media sosial sebenarnya bukanlah sekedar teknologi, tetapi merupakan sistem tekno-sosial yang memiliki bentuk teknologi fisik yang memungkinkan dan membatasi tingkat sosial kegiatan manusia dalam menciptakan pengetahuan, menyebar dan dikonsumsi dengan bantuan perangkat teknologi (Fuchs, 2013). Media sosial telah menjadi wadah reproduksi budaya dalam sebuah kelas sosial. Meskipun secara tidak langsung mendefinisikan media sosial, dalam pandangan Bourdieu (1984), media sosial adalah sebuah bentuk wadah kekuatan sosial dan struktur sosial dibuat melalui reproduksi budaya dalam perubahan sosial untuk melanggengkan dominasi melalui selera.

"Pembedaan selera, dan itu membagi penikmatnya. Subyek sosial diklasifikasikan berdasarkan klasifikasi selera mereka, membedakan diri mereka melalui perbedaan yang mereka buat, antara yang cantik dan yang jelek, yang terhormat dan yang vulgar, di mana posisi mereka secara objektif dibedakan, diungkapkan atau dperlihatkan”. (P Bourdieu, 2013).

Dari pernyataan ini, menurut Bourdieu produksi budaya dalam media sosial pada dasarnya bersifat relasional dan tak terpisahkan darinya. Seseorang tidak dapat menciptakan perbedaannya sendiri melainkan dibentuk oleh sebuah dominasi dalam kelas sosial dengan 
cara menyesuaikan diri dalam ruang-ruang sosial yang dikenal dengan arena. Bourdieu menjelaskan signifikansi relasional dari penentuan posisi sosial berdasarkan tujuan, keberadaan dan kapital yang dimiliki dalam distribusi kekuasaan dalam struktur sosial.

"Dalam istilah analitis, arena dapat didefinisikan sebagai jaringan, atau konfigurasi, hubungan obyektif antar posisi. Posisi-posisi ini secara obyektif didefinisikan atas keberadaan, dan diterapkan pada penghuni, agen atau institusi mereka, atas keberadaan dan situasi potensial mereka berdasar struktur distribusi jenis kekuasaan (atau kapital) yang dimiliki sebagai akses untuk menguasai keuntungan tertentu yang dipertaruhkan di arena, sebagaimana ditentukan oleh hubungan obyektif atas posisi yang lainnya" (Pierre Bourdieu \& Wacquant, 1992).

Bourdieu melihat kekuasaan yang utamanya dicirikan oleh seberapa tingginya tingkat kapital ekonomi dan kapital budaya. Dengan menggunakan konteks arena yang ditawarkan Bourdieu maka media sosial seperti facebook, twitter, dan instagram merupakan sebuah arena sosial yang merupakan tempat persaingan dengan menggunakan kode-kode tertentu. Menurut Fusch, media sosial dalam masyarakat dibentuk oleh struktur kekuatan ekonomi, politik dan budaya. Media sosial memiliki struktur kepemilikan tertentu yang dimiliki oleh kekuatan ekonomi tertentu. Media sosial memiliki struktur pengambilan keputusan tempat kelompok tertentu mengontrol pengambilan keputusan dan media sosial memiliki mekanisme khusus untuk menghasilkan reputasi dan popularitas dan tempat kekuatan budaya lebih terdistribusi secara tidak merata. Melalui media sosial, penggunanya melakukan posting sebagai interaksi dengan tujuan untuk berusaha melakukan perjuangan dalam dominasi kelas tertentu. Pengguna menggunakan media sosial karena mereka berusaha untuk mencapai tingkat tertentu dalam kapital sosial (akumulasi hubungan sosial), kapital budaya (akumulasi kualifikasi, pendidikan, pengetahuan) dan kapital simbolik (akumulasi reputasi) (Kamphuis, Jansen, Mackenbach, \& Van Lenthe, 2015).

Pentingnya kapital dalam sebuah arena menunjukkan bahwa media sosial bukanlah sekedar bentuk platform yang partisapatif, melainkan sebuah arena kontestasi sosial bagi individu didalamnya. Kepemilikan kapital yang tepat dalam penggunaanya merupakan sarana mendominasi kelas sosial yang lainnya dalam interaksi di media sosial.

\section{Selebriti dan Kapital}

Pada awalnya selebriti secara historis dikenal karena ketenaran individu yang berkaitan dengan keagamaan, namun dalam perkembangannya definisi selebriti 
dikonseptualisasikan sebagai bentuk ketenaran tertentu sebagai produk kapitalisme yang menyiratkan hubungan khusus melalui visibilitas publik dan dimediasi oleh media yang kadang kalanya tidak berkaitan dengan prestasi tertentu (Drake, Higgins, Holmes, \& Redmond, 2006). Menurut Adorno dalam industri budaya, dapat dipahami selebriti sebagai produk dari industri selebritas atau sebagai komoditas, sebagai sesuatu hasil produksi yang dapat dikonsumsi, dan dipuja (Cashmore dan Parker 2003 dalam Driessens, 2013). Membicarakan selebriti, tidak lepas dari estetika, keindahan dan selera dalam kehidupan sehari-hari. Filosof Jerman Alexander Baumgarten menciptakan istilah estetika pada 1750an yang mengacu pada sifat dan persepsi keindahan yang menetapkan kehormatan dan dihormati orang lain (Rojek, 2001). Media mempunyai peran penting sebagai gatekeeper dalam membedakan orang biasa dan selebriti untuk tampil di media menjadi konsumsi publik. Selebriti yang sukses di media kadang juga memasuki arena sosial lain selain hiburan seperti bidang politik, sastra, musisi atau jurnalistik menggunakan status selebriti mereka.

Selebriti juga hadir ditengah publik lewat sosial media. Dengan modal ketenarannya hampir dipastikan para selebriti mempunyai banyak pengikut (follower). Terinspirasi oleh Marx, Bourdieu memaparkan adanya perbedaan kapital tiap individu dalam stratifikasi sosial. Pembagian kapital yang dilakukan oleh Bourdieu berbeda dengan Marx yang hanya berdasarkan kapital ekonomi. Bourdieu menggabungkan dengan pemikiran Weber bahwa diferensiasi sosial terjadi bersamaan dengan munculnya lingkup nilai otonom yang mengakibatkan individu mengumpulkan dan memobilisasi berbagai jenis kapital. Jenis kapital yang ditawarkan Bourdieu adalah kapital ekonomi, kapital budaya, kapital sosial dan kapital simbolik.

"Bergantung pada arena dimana itu berfungsi, dan dengan memperhitungkan biaya yang ditransformasikan sebagai prasyarat keberhasilan dalam arena. Kapital dapat berwujud dalam tiga bentuk model yang fundamental yakni sebagai kapital ekonomi, yang dapat serta merta dan langsung dikonversi menjadi uang dan dapat dilembagakan dalam bentuk hak milik. sebagai kapital budaya, yang dapat dikonversi, pada kondisi tertentu, menjadi kapital ekonomi dan dapat dilembagakan dalam bentuk kualifikasi pendidikan. Dan sebagai kapital sosial, yang terdiri dari obligasi sosial (koneksi), yang dapat dikonversi dalam kondisi tertentu, menjadi modal ekonomi dan dapat dilembagakan dalam bentuk gelar kehormatan. (Pierre Bourdieu, 1985).

Posisi individu dalam arena sangat bergantung pada besarnya kapital dan konfigurasi yang dimiliki. Dua kapital terpenting adalah kapital ekonomi dan budaya. Kapital ekonomi dapat secara langsung dikonversi menjadi uang dan dilembagakan dalam bentuk hak milik. 
Sedangkan kapital budaya diwujudkan dalam bentuk disposisi pikiran dan butuh waktu yang lama sehingga dapat dipandang sebagai produk budaya. Sedangkan kapital simbolik diartikan sebagai kapital dalam bentuk apapun untuk mewakili, dipahami secara simbolis terkait pengakuan baik terinstitusionalisasi ataupun tidak.

Bourdieu mengungkapkan dalam setiap arena, individu yang "bertarung" dan ingin menguasai arena harus mempunyai kapital tertentu. Kapital yang dimiliki selebriti apabila dipandang dengan konsep kapital yang ditawarkan oleh Bourdieu, apakah mempunyai kapital simbolis atau tidak harus dilihat dari bagaimana pengakuan selebriti itu sebagai simbol dalam bentuk legitimasi. Dengan kata lain konversi kapital selebriti menjadi kekuatan simbolik bergantung pada memenangkan pengakuan publik dari mereka yang memiliki kekuasaan di arena (Arthurs \& Shaw, 2016). Selebriti mendapatkan kapital simbolis akibat akumulasi visibilitas media yang dihasilkan dari representasi media berulang, karena sifatnya yang cepat, berulang dan sementara kadang ada anggapan kapital selebriti dan kapital simbolik adalah dua hal yang berbeda (Driessens, 2013).

Pada prakteknya selebriti kerapkali yang mempunyai kapital simbolik dan menggunakan status mereka dalam banyak hal seperti marketing dan periklanan. Dalam media sosialpun dikenal istilah endorse, menggunakan jasa selebriti dalam mempromosikan suatu produk atau layanan jasa. Beberapa penelitian akademis telah dilakukan untuk melihat endorsement selebriti mempengaruhi iklan, brand positioning, dan usaha dalam niatan membeli (Keel, 2012:694). Dalam penelitian yang dilakukan Agyemang dan Williams pada selebriti basket NBA di Amerika menunjukkan pengikut di media sosial media telah ikut mendukung selebritis, ikut dalam menyebarluaskan merek, dan berpeluang mempunyai peran dalam media lain seperti televisi dan film (Williams, 2016). Kapital simbolik yang dimiliki oleh selebriti dapat mengakumulasi kapital yang lain yakni kapital sosial dengan adanya para pengikut yang sebagian besar adalah fans. Besarnya kapital sosial tergantung pada jumlah orang yang dapat dimobilisasi dalam jaringan individu, dalam hal ini melalui media sosial.

\section{Distinction Selebriti Dalam Media Sosial}

Bourdieu dalam bukunya Distinction: A Social Critique of the Judgement of Taste membagi tiga kelas sosial berdasarkan profesinya yakni kelas dominan, kelas borjuis kecil (petite bourgeoisie) dan kelas populer. Kelas dominan ditandai dengan kepemilikan modal yang besar, menentukan budaya yang berlaku dan mempunyai kemampuan untuk mengakumulasi semua jenis kapital. Kelas borjuis kecil meskipun dianggap termasuk kelas borjuis tetapi mereka ditempatkan diposisi kelas menengah yang berusaha menaiki tangga 
sosial. Kelas ini mempunyai ciri sangat menghormati tatanan sosial dan menjunjung tinggi moral. Dalam kelas ini terbagi lagi menjadi borjuis kecil dalam situasi keruntuhan, borjuis pelaku dan borjuis kecil baru yang memiliki modal budaya besar namun lemah dalam modal sosial. Kelas sosial terakhir yang dikategorikan Bourdieu adalah kelas populer, sebuah tingkat kelas yang tidak mempunyai kepemilikan kapital seperti kelas buruh pabrik dan tani (Haryatmoko, 2015).

Pengkategorian kelas sosial memasukkan selebriti yang mempunyai kapital simbolik dalam kelas dominan karena selebriti dapat menentukan budaya yang bisa dinikmati oleh kelas yang lain, selain itu kemampuan selebriti menggunakan kapital simboliknya melalui kapital sosial menjadi kapital ekonomi semakin memperkuat status mereka di kelas dominan. Adanya kelas dominan kerapkali selalu membedakan atau ingin tampak berbeda di kelas sosial dibawahnya. Menurut Bourdieu, selera konsumsi adalah salah satu cara untuk membedakan diri antar kelas yakni melalui makanan, budaya dan penampilan melalui kapital simbolik yang dikenal dengan istilah distinction.

“... di dalam kelas yang dominan, seseorang dapat, secara sederhana, dibedakan dalam tiga struktur konsumsi yang didistribusikan dalam tiga bentuk: makanan, budaya dan presentasi (pakaian, perawatan kecantikan, perlengkapan mandi, pembantu rumah tangga). Struktur-struktur ini mengambil bentuk yang bertentangan - seperti struktur kapital mereka (P Bourdieu, 2013:279).

Distinction selebriti pada media sosial dapat ditemui dari yang mereka posting ataupun yang mereka komentari untuk memperlihatkan pembedaan kelas. Beberapa kasus misalnya seringkali selebriti identik hadir melalui foto dan video dalam tampilan yang mewah dan berharga mahal. Contohnya, pagelaran pemberian piala Oscar kerap menjadi ajang selebriti untuk menampilkan penampilan dengan harga ribuan dolar (harpersbazaar.com, 2018). Tidak hanya penampilan berpakaian, foto tempat pelesir selebriti juga kerapkali diunggah untuk memperlihatkan kepada follower nya agar tampak berbeda dan istimewa (http://people.com/, 2018). Selain penampilan, menu makanan juga menjadi distinction dalam membedakan kelas sosial, CEO Amazon Jeff Bezos misalnya yang terpublikasi menikmati menu makanan yang unik yakni di restoran mewah dengan menu masakan hewan iguana (businessinsider.com, 2018). 


\title{
Habitus dan Media Sosial
}

Media sosial di era teknologi telah menjadi sebuah arena tempat kekuasaan dilanggengkan, budaya dominan tetap berusaha diberlakukan. Aksi dan tindakan dalam media sosial dan dunia fisik tidaklah jauh berbeda, keduanya didasarkan habitus yang dialami oleh individu. Habitus diperkenalkan oleh Bourdieu sebagai sebuah produk sejarah yang menghasilkan praktik individu dan kolektif yang ditentukan dalam proses internalisasi sebelumnya. Bourdie mendefinisikan habitus seringkali diterima dalam ketidaksadaran yang hadir dari pengalaman sejarah yang disimpan dalam setiap individu dalam bentuk skema persepsi, pemikiran dan tindakan, cenderung untuk menjamin 'kebenaran' praktik dan keteguhannya dari waktu ke waktu, dan keberadaannya lebih kuat daripada semua aturan formal dan eksplisit norma. Habitus merupakan sebuah disposisi dalam struktur sosial yang terbentuk secara sistematis yang menjadi gaya hidup.

\begin{abstract}
Habitus adalah kebutuhan yang diinternalisasi dan diubah menjadi disposisi yang menghasilkan praktik yang penuh makna dan persepsi yang memberi makna, sebagai disposisi umum transposabel, yang membentuk aplikasi yang universal melampaui batas-batas apa yang telah dipelajari secara langsung terkait kebutuhan yang melekat dalam kondisi pembelajaran. Itulah sebabnya seluruh rangkaian praktik agen atau seluruh kumpulan agen yang dihasilkan oleh kondisi serupa keduanya terbentuk sistematis, karena mereka adalah produk penerapan skema identik (atau dapat dipertukarkan), dan secara sistematis berbeda dari praktik merupakan gaya hidup lain (P Bourdieu, 2013:261).
\end{abstract}

Habitus secara sadar atau tidak telah membentuk dan mewujudkan selera tertentu yang dimanifestasikan dalam rutinitas konsumsi dalam suatu kegiatan (Lee, Scott, \& Packer, 2014). Habitus mempunyai dua prinsip yakni pertama, sens pratique yang berupa kemampuan individu untuk melakukan penyesuaian habitus secara spontan saat berada dalam arena dan bagaimana dia bertindak, sedangkan yang kedua adalah illusio kepercayaan diri individu dalam arena meskipun individu tersebut tidak benar-benar memahami arena dia berada. Bourdie mengandaikan dua prinsip habitus seperti permainan, hampir semua berjalan dengan ketidaksadaran yang ditanamkan pada masa lalu untuk sebuah implikasi di masa depan. Untuk dapat lepas dari ketidaksadaran yang terbentuk ini individu harus keluar dari permainan yang dijalaninya.

Individu hanya perlu berdiri di luar permainan, seperti yang dilakukan pengamat, untuk menghapus urgensi, daya tarik, ancaman, mengambil langkah menuju kenyataan dunia yang sebenarnya Hanya untuk seseorang yang benar-benar 
menarik diri dari permainan, yang benar-benar mematahkan mantra, ilusio, melepaskan diri semua pertaruhan di masa depan... Perasaan' (sens) dalam permainan adalah sensasi akan masa depan yang yang datang dari permainan, sensasi arah (sens) dari sejarah permainan itu yang memberikan rasa dari permainan rasa (Pierre Bourdieu, 1990).

Meskipun tidak langsung menyinggung tentang hubungan langsung keberadaan teknologi dan habitus, tapi dengan menggunakan teori habitus dan arena Bourdieu, keberadaan teknologi yang berkarakteristik interaktif dapat diterapkan konsep habitus didalamnya. Keberadaan teknologi media sosial sebagai media komunikasi telah menjadi elemen habitus dari individu yang menggunakannya. Media sosial telah menjadi bagian dari habitus yang telah memindahkan identitas kelas dan pengaruh kekuasaan dominan, arena mengeksploitasi habitus dan tempat mengakumulasi modal. Penggunaan teknologi, konten dan teks dalam media sosial dianggap erat dengan tingkat perbedaan kelas. Hal ini ditegaskan dari hasil penelitian yang dilakukan Willig dan kawan-kawan bahwa terdapat hubungan antara kapital budaya, habitus, dan bentuk budaya yang menghasilkan kesenjangan penggunaan media digital yang secara sosial mengakar bersumber pada masalah ekonomi (Willig, Waltorp, \& Hartley, 2015).

Mengacu pada pengertian bahwa habitus menjadi bagian dari media sosial sebagai arena, maka tidak mengherankan seringkali selebriti menggunakan media sosial sebagai ranah untuk menambah atau mengakumulasi kapital yang dimiliki. Media sosial telah menjadi arena untuk melipatgandakan kapital buat beberapa individu atapun kelompok dengan melakukan komodifikasi tertentu. Iklan dan endorsment selebiriti di media sosial adalah salah satunya, banyak perusahaan baik barang maupun jasa cenderung menggunakan selebriti sebagai endorser untuk produk mereka. Kehadiran media sosial telah membantu peorangan dan perusahaan membangun kehadiran sosial dan memberi tahu orang lain tentang produk dan layanan. Popularitas penggunaan media sosial sebgai alat pemasaran dan periklanan semakin meningkat karena perusahaan menyadari potensi media sosial dalam mencapai tujuan untuk mengumpulkan keuntungan melalui periklanan di dalamnya. Melalui media sosial, perusahaan memungkinkan menjangkau jutaan orang, di seluruh dunia, dan meningkatkan jumlah pelanggan berkali-kali lipat (Kennedy, 2016).

Penggunaan selebriti yang tepat diyakini dapat mendongkrak penjualan dan memunculkan konsumsi lebih banyak. Bahkan sebuah penelitian menunjukan bahwa dengan memakai selebriti asing akan menghasilkan keefektifan iklan yang maksimal (Dom, Ramli, Chin, \& Fern, 2016). Hasil penelitian ini menunjukkan bagaimana habitus yang dimikili oleh 
selebriti dan publik dalam media saling berkaitan, selebriti melakukan dominasi melalui iklan dalam media sosial yang menghasilkan perilaku konsumsi buat orang lain.

\section{Komodifikasi Kapital dan Kemunculan Selebriti Baru}

Cashmore telah melakukan analisa hubungan yang dimiliki selebriti dengan komodifikasi dan masyarakat konsumen serta meneliti penggunaan media baru (media sosial) yang memperlihatkan bahwa budaya selebriti kerap muncul seiring adanya komodifikasi. Komodifikasi yaitu proses di mana segala sesuatu, termasuk figur publik diubah menjadi sebuah komoditas perdagangan yang dipertukarkan di pasar (Cashmore, 2006). Media sosial sebagai arena yang digunakan untuk memperkuat dominasi kelompok tertentu seperti selebriti kemudian berubah sedemikian rupa melalui komodifikasi dengan seolah-olah kedekatan selebriti dengan follower untuk berbagi selera yang sama. Penciptaan selera yang sama di media sosial oleh selebriti sebenarnya sebuah arena baru tempat dimana konversi kapital simbolik di konversi menjadi kapital ekonomi melalui sebuah komodifikasi produk milik selebriti.

Salah satu fenomena terbaru selebriti di Indonesia adalah kehadiran produk makanan, resto kuliner, kosmetik dan merek-merek produk milik selebriti melalui media sosial. Awalnya selebriti yang identik dengan kelas sosial yang tampil berbeda dan mewah dan tidak mau terlihat identik dengan fans atau pengikutnya kini berusaha mendekatkan diri dengan pengikutnya melalui brand milik selebriti (hipwee.com, 2017). Tercatat beberapa selebriti Indonesia telah membuka bisnis melalui usaha kuliner dari kue hingga restoran. Anggapan ketenaran mereka tidak akan bertahan lama sehinga selebriti memilih usaha yang lain. Meskipun pamor atau kapital simbolik yang dimiliki oleh selebriti belum hilang namun mereka telah menciptakan komodifikasi dengan kapital simboliknya untuk memperoleh kapital ekonomi.

Sebagai arena baru, memungkinkan munculnya selebriti baru dalam media sosial. Dalam pandangan lama selebriti identik dengan visiblitas yang didapatkan melalui media. Namun pada media sosial dengan karakter pastisipatifnya telah memunculkan selebritiselebriti baru dalam media sosial yang disebut dengan micro celebrity. Terri Senft, dalam bukunya Camgirls: Celebrity and Community in the Age of Social Networks, mendefinisikan micro celebrity sebagai gaya baru dari penampilan online di mana orang menggunakan webcam, video, audio, blog, dan situs jejaring sosial untuk menaikkan popularitas mereka di kalangan pembaca, pemirsa, dan mereka yang terhubung secara online (Marwick, 2013). Ditinjau dari teori arena dan kapital yang dikemukakan Bourdieu, kemunculan-kemunculan 
selebriti baru ini sebenarnya adalah bentuk kemampuan seseorang memobilasasi kapital yang dia miliki untuk mendapatkan kemampuan mendominasi. Fenomena micro celebrity terbaru di Indonesia adalah munculnya selebgram (selebriti instagram) yang mempunyai latar belakang beragam dan tidak semuanya mempunyai kepopuleran sebelumnya melalui media televisi. Ada beberapa tipikal micro celebrity yang mempunyai pengaruh dalam media sosial:

a. Social butterfly. Selebgram dengan tipe ini memiliki jumlah pengikut yang besar. Kekhasan mereka yaitu jangkauan jaringan pertemanan yang luas dan beragam. Hal ini menguntungkan bagi pengiklan yang ingin meningkatkan awareness produknya di media sosial

b. Penggalang Opini. Selebgram dengan kemampuan membangun opini biasanya didengar banyak orang karena dianggap memiliki akses ke bidang tertentu. Selebgram dengan tipe ini memiliki kemampuan untuk menciptakan percakapan di antara para pengguna Instagram

c. Trendsetter. Sang pencipta tren. Itulah karakter yang dimiliki selebgram dengan tipe ini. Mereka adalah orang yang selalu ingin menjadi yang pertama dalam mencoba berbagai produk baru. Dalam dunia pemasaran, selebgram dengan tipe ini sangat cocok untuk mempromosikan produk yang baru diluncurkan

d. Selebriti. Selebriti yang juga menjadi selebgram merupakan tipe selebgram yang paling banyak pengikutnya. Hal ini karena mereka sudah terlebih dulu memiliki basis penggemar

e. Pakar. Seorang pakar bisa jadi tidak bisa sepopuler selebgram dari kalangan selebriti. Namun, selebgram tipe ini memiliki keahlian di bidang tertentu yang membuat pendapatnya didengar banyak orang (vik.kompas.com, 2017).

Munculnya micro celebrity baru melalui media sosial merupakan budaya abad 21 akibat kehadiran media baru sebagai arena baru mengubah yang biasa menjadi yang luar biasa yang menarik perhatian. Menurut sosiolog Inggris Chris Rojek (2001), terdapat tiga macam bentuk selebriti:

1. Ascribed celebrity: status selebriti yang telah ditentukan berdasarkan garis keturunan, seperti anggota keluarga kerajaan atau anak dari orang-orang terkenal.

2. Achieved celebrity: status selebriti yang diberikan kepada individu yang mencapai kebesaran berkat bakat, keterampilan, atau kualitas khusus. 
3. Attributed celebrity: individu menjadi selebriti tanpa memiliki bakat hebat atau garis keturunan yang terkenal. Selebriti mereka sepenuhnya dihasilkan media (Laughey, 2010).

Dari beberapa tipikal selebgram, dapat dilihat bagaimana kapital yang dimobilasasi dalam media sosial, seperti pada tipikal social butterfly dan penggalang opini mempunyai karakteristik kepemilikan jaringan pertemanan (koneksi luas). Kapital yang berkaitan dengan jaringan sosial menurut Bourdieu merupakan jenis kapital sosial yang memperlihatkan kekuasaan individu untuk memperkuat dominasinya khususnya dalam konteks kepercayaan sosial (Siisiäinen, 2000). Sedangkan pada tipikal trendsetter, individu yang memiliki kemampuan kapital ekonomi tinggi akan lebih mudah menjadi selebriti tipe ini dan akan lebih mudah mendapatkan produk-produk baru dan menjadi figur yang dominan dalam membuat tren. Seperti yang diungkapkan Bourdieu bahwa kapital ekonomi merupakan kapital yang paling mudah dikonversi ke bentuk kapital yang lain, dengan mempunyai uang yang berlebih maka individu dapat menjadi micro celebrity dengan mengkonversi kapital ekonominya ke bentuk kapital sosial lewat tren mode yang mendapat perhatian dari banyak follower. Selebgram tipe pakar merupakan selebriti media sosial yang lebih memobilasi kapital budayanya atas pengetahuan dan keahlian tertentu yang didapatkan melalui pendidikan. Sedangkan tipe selebriti adalah selebriti yang mempunyai kapital simbolik yang didapatkannya melalui legitimasi dan intensitas visibilitas melalui media massa sebelumnya.

Micro celebrity juga pada akhirnya mengakumulasi kapital-kapital yang dimilikinya menjadi kapital lain seperti kapital simbolik dan ekonomi. Menjadi selebriti berarti sama dengan menjadi kelas sosial yang dominan dalam arena sosial, yang mempunyai kekuasaam untuk mendominasi dan berusaha mengambil keuntungan dari hal tersebut seperti mendapatkan keuntungan (kapital ekonomi) melalui endorse dan iklan di banyak bidang. Kehadiran selebriti konvensional dan micro celebrity telah dipersepsikan kredibel dalam konsumen dari berbagai usia, jenis kelamin, agama, dan lainnya (Jargalsaikhan, Korotina, \& Pantelic, 2016).

\section{Kesimpulan}

Media sosial sebagai arena yang muncul dalam bentuk digital sebenarnya tidak berbeda dengan arena dalam bentuk fisik. Dalam arena terdapat usaha melakukan dominasi kelas sosial tertentu dengan memanfaatkan kapital yang dimiliki, termasuk oleh selebriti melalui distinction untuk memperlihatkan perbedaan kelas. Selebriti yang awalnya 
mempunyai kapital simbolik melalui visibilitas oleh media telah diakumulasi dan dikonversi menjadi kapital lain di media sosial. Komodifikasi selebriti menjadi produk pemasaran telah meningkatkan kemampuan kapital lain, khususnya kapital ekonomi melalui kehadiran follower.

Meskpiun kadang selebriti berusaha menempatkan dirinya sejajar dengan kelas sosial yang lain namun sebenarnya aksi sosial itu merupakan bentuk cara mengakumulasi kapital yang dimiliki. Menurut Boyd dan Marwick (2011), media sosial telah menciptakan peluang bagi orang untuk menjadi terkenal dan terlihat di antara sekelompok pengguna dalam saluran tertentu (Jargalsaikhan et al., 2016). Media sosial sebagai arena yang mengubah hal biasa menjadi luar biasa dan menarik perhatian juga menghasilkan micro celebrity akibat kemampuan individu memobilisasi kapital yang dimiliki. Menurut Marwick (2010), praktek micro celebrity melihat pengikut mereka sebagai basis penggemar dan memanfaatkan mereka dengan membangun persona secara online mereka untuk konsumsi orang lain (Rahmawan, 2014).

Untuk menjadi terkenal dalam arena sosial penting untuk memobilisasi kapital yang dimiliki, dalam media sosial khususnya, perlu memiliki jaringan luas orang-orang yang berpengaruh (kapital sosial) dan juga memiliki bakat khusus (kapital budaya). Dalam beberapa arena tertentu, seperti media sosial, kapital ekonomi juga mempunyai peran penting sebagai pemikat dan pembeda selera yang mendapatkan atensi. Dominasi kelas sosial selebriti terkadang tidak disadari oleh follower, dan hanya menguntungkan pada selebriti. Ketidaksadaran follower yang dibuktikan dengan tindakan mengkonsumsi produk milik selebriti agar merasa sejajar merupakan sebuah habitus yang menjadi pola pikir dan perilaku follower. Penciptaan selera yang sama hanyalah bentuk distinction lain yang dilakukan untuk melanggengkan kelas dominan selebriti melalui akumulasi kapital ekonomi.

\section{Referensi.}

Arthurs, J., \& Shaw, S. (2016). Celebrity capital in the political field: Russell Brand's migration from stand-up comedy to Newsnight. Media, Culture and Society, 38(8), 1136-1152. https://doi.org/10.1177/0163443716635869

Bourdieu, P. (1985). The Forms of Capital. Handbook of Theory of Research for the Sociology of Education, (1), 46-58.

Bourdieu, P. (1990). The Logic of Practice. Studies in Philosophy and Education (Vol. 7). Stanford University Press. https://doi.org/10.1007/BF00680104

Bourdieu, P. (2013). Distinction: A Social Critique of the Judgement of Taste. Taylor \& Francis.

Bourdieu, P., \& Wacquant, L. J. D. (1992). An Invitation to Reflexive Sociology. An Invitation to reflexive sociology. Polity Press. 
https://doi.org/10.1017/CBO9781107415324.004

businessinsider.com. (2018). Here's a picture of Amazon CEO Jeff Bezos eating an iguana | Business Insider. Retrieved March 31, 2018, from https://www.businessinsider.com.au/heres-a-picture-of-amazon-ceo-jeff-bezos-eatingan-iguana-2018-3

Burson-Marstellery. (2017). Twiplomacy study 2017. Twiplomacy. Retrieved from http://twiplomacy.com/blog/twiplomacy-study-2017/

Cashmore, E. (2006). C E L E B R I T Y / C U L T UR E. New York: Routledge.

Dom, S. M. S. M., Ramli, H. S. binti, Chin, A. L. L., \& Fern, T. T. (2016). Determinants of the effectiveness of celebrity endorsement in advertisement. The Journal of Developing Areas, 50(5), 525-535. https://doi.org/10.1353/jda.2016.0033

Drake, P., Higgins, M., Holmes, S., \& Redmond, S. (2006). Framing celebrity.

Driessens, O. (2013). Celebrity capital: Redefining celebrity using field theory. Theory and Society, 42(5), 543-560. https://doi.org/10.1007/s11186-013-9202-3

Coman, C., \& Paun, M. (2010). The image og the public institutions and new technologies. Romanian Journal of Journalism \& Communication, (4), 45-53.

facebook.com. (2018). Facebook -Audience Insights. Retrieved April 23, 2018, from https://www.facebook.com/ads/audience-insights/people?act $=356058902 \&$ age $=18$ \& city $=962899$

Fuchs, C. (2013). Social Media: A Critical Introduction. Social Media: A Critical Introduction. https://doi.org/10.1097/CIN.0000000000000147

Gironda, J. T., \& Korgaonkar, P. K. (2014). Understanding consumers' social networking site usage. Journal of Marketing Management, 30(5-6), 571-605. https://doi.org/10.1080/0267257X.2013.851106

harpersbazaar.com. (2018). Expensive red carpet dresses ranked - from the Oscars to the Golden Globes. Retrieved March 31, 2018, from https://www.harpersbazaar.com/uk/fashion/style-files/news/g38203/expensive-redcarpet-dresses/?slide $=1$

Haryatmoko. (2015). Membongkar Rezim Kepastian: Pemikiran Kritis Post-Strukturalis. PT Kanisius.

hipwee.com. (2017). Tren Baru! Deretan 30 Artis Indonesia yang Menggeluti Bisnis Kue Oleh-Oleh Khas Kekinian. Retrieved March 31, 2018, from https://www.hipwee.com/opini/tren-baru-deretan-30-artis-indonesia-yang-menggelutibisnis-kue-oleh-oleh-khas-kekinian/

http://people.com/. (2018). Celebrity Vacations: Where Stars Get Away | PEOPLE.com. Retrieved March 31, 2018, from http://people.com/home/celebrity-vacations/\#heidiklum

Humphreys, L. (2007). Mobile social networks and social practice: A case study of dodgeball. Journal of Computer-Mediated Communication, 13(1), 341-360. https://doi.org/10.1111/j.1083-6101.2007.00399.x

Jargalsaikhan, T., Korotina, A., \& Pantelic, D. (2016). Attitudes towards Instagram microcelebrities and their influence on consumers' purchasing decisions Title: Attitudes towards Instagram micro-celebrities and their influence o $\mathrm{n}$ c onsumers' purchasing decisions.

Kennedy, G. (2016). Social Media: Master Social Media Marketing - Facebook, Twitter, Youtube \& Instagram. CreateSpace Independent Publishing Platform.

Kamphuis, C. B. M., Jansen, T., Mackenbach, J. P., \& Van Lenthe, F. J. (2015). Bourdieu's cultural capital in relation to food choices: A systematic review of cultural capital indicators and an empirical proof of concept. PLoS ONE, 10(8). https://doi.org/10.1371/journal.pone.0130695 
Keel, A. (2012). Celebrity Endorsements and Beyond : New Avenues for Celebrity Branding, 29(September), 690-703. https://doi.org/10.1002/mar

Kim, D. H., Seely, N. K., \& Jung, J. H. (2017). Do you prefer, Pinterest or Instagram? The role of image-sharing SNSs and self-monitoring in enhancing ad effectiveness. Computers in Human Behavior, 70, 535-543. https://doi.org/10.1016/j.chb.2017.01.022

Laughey, D. (2010). Media Studies: Theories and Approaches. London. London: Oldcastle Book.

Lee, K. H., Scott, N., \& Packer, J. (2014). Habitus and food lifestyle: In-destination activity participation of Slow Food members. Annals of Tourism Research, 48, 207-220. https://doi.org/10.1016/j.annals.2014.06.009

Malik, A., \& Sudhakar, B. D. (2014). Brand Positioning Through Celebrity Endorsement - A Review Contribution to Brand Literature. International Review of Management and Marketing, 4(4), 259-275.

Marwick, A. E. (2013). Status Update - Celebrity, Publicity, And Branding In The Social Media Age. Yale University Press b.

Parveen, F. (2012). Impact of social media usage on organizations. Pacific Asia Conference on Information Systems (PACIS), 12. Retrieved from http://aisel.aisnet.org/pacis2012/192\%0A

Phillips, D., \& Young, P. (2009). Online public relations: A practical guide to developing an online strategy in the world of social media. Managing. London: Kogan Page.

Rahmawan, D. (2014). Selebtwits: Micro-Celebrity Practitioners In Indonesian Twittersphere, 2(1), 1-11.

Rojek, C. (2001). Celebrity. London: Reaktion Books Ltd.

Sigh, D. K. P., Bebi, \& Gulati, D. (2011). Technological March from Web 1 . 0 to Web 3 . 0 : A Comparative Study. IndianJournals.Com, 49(2), 146-157.

Siisiäinen, M. (2000). Two Concepts of Social Capital: Bourdieu vs. Putnam. North, 40(2), 183-204. https://doi.org/10.1083/jcb.200611141

Solanki, M. R., \& Dongaonkar, A. (2016). A Journey of Human Comfort: Web 1.0 to Web 4.0. International Journal of Research and Scientific Innovation (IJRSI), III(September 2016), 75-78.

topteny.com. (2018). Top 10 Most Popular Celebrities on Social Media for 2018. Retrieved from https://www.topteny.com/top-10-popular-celebrities-social-media-2018/

tribunnews.com. (2017). Daftar Selebrita Dunia dan Indonesia dengan Follower Instagram Terbanyak 2017. Retrieved from http://m.tribunnews.com/amp/seleb/2017/12/01/daftarselebrita-dunia-dan-indonesia-dengan-follower-instagram-terbanyak-2017?page $=3$

vik.kompas.com. (2017). Selebgram - Menguak Layar Bisnis Selebgram. Retrieved from https://vik.kompas.com/selebgram/

wearesocial.com. (2018a). Digital in 2018: World's internet users pass the 4 billion mark We Are Social UK. Retrieved April 28, 2018, from https://wearesocial.com/uk/blog/2018/01/global-digital-report-2018

wearesocial.com. (2018b). Digital in Southeast Asia in 2017 - We Are Social. Retrieved April 9, 2018, from https://wearesocial.com/special-reports/digital-southeast-asia-2017

wearesocial.com. (2018c). Social media use jumps in Q1 despite privacy fears - We Are Social. Retrieved May 17, 2018, from https://wearesocial.com/blog/2018/04/socialmedia-use-jumps-in-q1-despite-privacy-fears

Williams, A. S. (2016). Managing celebrity via impression management on social network sites An exploratory study of NBA celebrity athletes. https://doi.org/10.1108/SBM-072015-0021

Willig, I., Waltorp, K., \& Hartley, J. M. (2015). Field theory approaches to new media practices: An introduction and some theoretical considerations. MedieKultur: Journal of 
Media and Communication Research, $\quad 31(58), \quad 1$.

https://doi.org/10.7146/mediekultur.v31i58.20671 